\title{
PERTUMBUHAN DAN HASIL TANAMAN PADI VARIETAS INPARI 23 PADA TIGA JENIS TANAH YANG MENDAPAT PEMBENAH DENGAN BERBASIS PUPUK ORGANIK BIO-SLURRY
}

\author{
Puguh Jati Nugroho 1), Sumarsono 2), dan Sutarno ${ }^{3)}$ \\ 1,2,3) Program Studi Agroekoteknologi, Fakultas Peternakan dan Pertanian Universitas Diponegoro, \\ JI. Prof. Soedarto, SH., Tembalang, Semarang, Telp (024) 7465403, Email : \\ puguhjati.n@gmail.com
}

\begin{abstract}
Abstrak
Penelitian bertujan untuk mengevaluasi pengaruh pembenah tanah terhadap pertumbuhan dan produksi tiga tanaman padi verietas Inpari 23 pada tiga jenis tanah. Rancangan penelitian yang digunakan adalah percobaan split plot, dengan ulangan sebanyak 3 kali. Petak utama tanah asal lokasi yang terdiri dari jenis tanah andosol asal Karanganyar (L1), jenis tanah mediteran asal magelang (L2) dan jenis tanah aluvial asal Demak (L3). Anak petak yaitu tanpa pembenah (R1) dan dengan pembenah (R2). Parameter yang diamati adalah tinggi tanaman, jumlah anakan, bobot tajuk tanaman, dan indeks panen. Data yang diperoleh dianalisis secara statistik dengan menggunakan analisis ragam, kemudian dilanjutkan dengan uji BNT pada taraf $5 \%$ untuk melihat beda antar perlakuan. Hasil penelitian menunjukkan bahwa terdapat pengaruh interaksi nyata $(P<0,05)$ antara perlakuan pemberian pembenah tanah dengan jenis tanah asal tiga lokasi terhadap parameter jumlah anakan dan bobot bangkas tajuk tanaman. Berdasarkan hasil penelitian dapat disimpulkan bahwa pertumbuhan dan produksi padi varietas Inpari 23 tertinggi dengan pemberian pembenah tanah (R2) yaitu pada jenis tanah aluvial asal Demak (L3), diikuti jenis tanah mediteran asal Magelang (L2) dan andosol asal Karanganyar (L3).
\end{abstract}

Kata kunci : Padi ; Pembenah Tanah ; Pertumbuhan ; Pupuk Organik.

\begin{abstract}
The study was conducted to the effect of soil amendment on the growth and production of three Inpari 23 rice plants on three types of soil. The research design used was a split-plot experiment, with 3 replications. The main plot of soil from the location consisted of andosol soil type from Karanganyar (L1), Mediterranean soil type from Magelang (L2), and alluvial soil type from Demak (L3). Sub-plots are without soil amendment (R1) and with soil amendment (R2). Parameters observed were plant height, number of tillers, the weight of plant crown, and harvest index. The data obtained were statistically analyzed by analysis of variance prosedure, and the LSD test at the 5\% level for to comparation the difference mean between treatments. The results showed that the interaction effect between the treatment of soil improvement and the type of soil from three locations was significant $(P<0,05)$ based on the parameters of the number of tillers and the weight of the plant crown. The conclution of the study that the growth and production of the Inpari 23 variety were highest with soil improvement (R2 on the alluvial soil type from Demak (L3), followed by the Mediterranean soil type from Magelang. (L2) and of the andosol soil type from Karanganyar (L3).
\end{abstract}

Keywords: Growth; Paddy; Soil Repairer; Organic fertilizer.

\section{PENDAHULUAN}

Tanaman padi merupakan salah satu jenis tanaman pangan yang banyak dibudidayakan di Indonesia. Pada tahun 2017 luas lahan pertanian di Indonesia sebesar 37,1 juta hektar terdiri dari 11,7 juta hektar berupa tegal, 5,2 juta hektar ladang, 12 juta hektar lahan yang sementara tidak digunakan dan 8,1 juta hektar berupa sawah (Kementan, 2020). Produksi padi di Indonesia pada tahun 2018 sebesar 83.037.150 Ton dan produktivitas sebesar $51,92 \mathrm{Ku} / \mathrm{Ha}$ (BPS, 2019). 
Inpari 23 merupakan salah satu varietas padi aromatik yang banyak ditanam oleh petani. Varietas inpari 23 memiliki karakteristik umur tanaman kurang lebih 113 hari, rata-rata hasil 6,9 ton/ha GKG dengan potensi hasil sebesar 9,2 ton/ha GKG. Bentuk tanaman tegak dengan tinggi kurang lebih $112 \mathrm{~cm}$, gabah berwarna kuning berbentuk gemuk/lonjong, tekstur nasi pulen wangi pandan, ketahanan terhadap hama dan penyakit yaitu tahan terhadap wereng batang coklat, tahan terhadap penyakit hawar daun bakteri patotipe III, agak tahan patotipe IV, dan rentan patotipe VIII, baik ditanam di sawah dataran rendah sampai sedang yaitu 0-600 mdpl (Astriah et al., 2017).

Faktor yang mempengaruhi produktivitas dari tanaman padi yaitu faktor genetik dan lingkungan. Faktor genetik berkaitan dengan pewarisan sifat/perilaku tanaman itu sendiri, sedangkan faktor lingkungan berkaitan dengan kondisi lingkungan dimana tanaman itu tumbuh. Setiap varietas tanaman memiliki kemampuan yang berbeda dalam hal memanfaatkan sarana tumbuh dan kemampuan untuk melakukan adaptasi dengan lingkungan sekitar, sehingga mempengaruhi potensi hasil tanaman (Anggraini et al., 2013). Tanah merupakan salah satu komponen yang mempunyai peranan penting terhadap pertumbuhan tanaman dan produksi tanaman. Tanah selain berfungsi sebagai tempat atau media tumbuh tanaman tanah juga memiliki peran menahan dan menyediakan air serta unsur hara yang diperlukan bagi tanaman untuk mendukung pertumbuhan tanaman.

Kualitas tanah yang rendah menjadi salah satu penyebab rendahnya produktivitas lahan pertanian. Penyebab penurunan kualitas tanah dapat disebabkan oleh beberapa faktor antara lain faktor manusia yang tidak melakukan sistem pengelolaan lahan yang berkelanjutan. Pembenah tanah merupakan bahan - bahan yang digunakan untuk memperbaiki sifat struktur fisik tanah dan reaksi kimia $\mathrm{pH}$ tanah. . Fungsi pembenah tanah pada gilirannya dapat meningkatkan ketersediaan unsur hara, mempercepat dekomposisi bahan organik, meningkatkan kapasitas tukar kation (KTK) dan meningkatkan kapasitas tanah untuk menahan air dan unsur hara (Dariah et al., 2016). Bahan yang digunakan sebagai pembenah tanah dapat berupa bahan alami, sintetik maupun mineral.

Mineral yang dapat dijadikan sebagai pembenah tanah antara lain kapur dan dolomit. Menurut Silahooy (2018) kandungan $\mathrm{Ca}$ pada dolomit dapat meningkatkan $\mathrm{pH}$ pada tanah. Pemberian dolomit pada tanah berpasir dapat meningkatkan daya jerap air dan pemberian pada tanah liat dapat memperbaiki struktur tanah dan pori - pori tanah (Juarsah, 2016). Bahan lain yang dapat digunakan sebagai pembenah tanah selain mineral yaitu kompos. Penggunaan kompos sebagai pembenah tanah berfungsi untuk meningkatkan kandungan C-organik tanah sehingga memperbaiki sifat fisik tanah yaitu tanah menjadi gembur sehingga memperbaiki sistem perakaran tanaman, dan meningkatkan aerasi untuk kehidupan mikroba di dalam tanah (Prananda et al., 2014)..

Penggunaan pembenah tanah diharapkan dapat mendukung pertumbuhan tanaman padi. Oleh karena itu, perlu dilakukan penelitian tentang pengaruh pembenah tanah pada tiga jenis tanah asal tiga lokasi terhadap pertumbuhan dan produksi tanaman padi Inpari 23.

\section{METODE PENELITIAN}

Penelitian dilaksanakan pada tanggal 8 Agustus 2019 - 12 Desember 2019 di Greenhouse Fakultas Peternakan dan Pertanian, Universitas Diponegoro, Semarang. Analisis kimia laboratorium di Laboratorium Ekologi dan Produksi Tanaman, Fakultas Peternakan dan Pertanian, Universitas Diponegoro, 
Semarang. Penelitian ini akan dilaksanakan dengan menggunakan Split Plot $3 \times 2$ dengan ulangan sebanyak 3 kali. Petak utama tanah asal lokasi yang terdiri dari jenis tanah andosol asal Karanganyar (L1), jenis tanah mediteran asal Magelang (L2) dan jenis tanah aluvial asal Demak (L3). Anak petak pembenah tanah yang terdiri dari R1: Tanpa pembenah dan R2: Dengan pembenah (dolomit $10 \mathrm{~g} / \mathrm{kg}$ tanah dan pupuk organik $200 \mathrm{~g} / \mathrm{kg}$ tanah). Dolomit ditambahkan pada jenis tanah andosol asal Karanganyar dan jenis tanah mediteran asal Magelang. Pupuk organik ditambahkan pada jenis tanah mediteran asal Magelang dan jenis tanah aluvial asal Demak. Parameter yang diamati adalah tinggi tanaman, jumlah anakan, bobot brangkas bagian tajuk, dan indeks panen. Data yang diperoleh diolah secara statistik dengan menggunakan analisi ragam, kemudian dilanjutkan dengan uji BNT (Beda Nyata Terkecil) pada taraf 5\%.

Sampel tanah yang digunakan dalam penelitian adalah tanah jenis andosol (Desa Jungke, Karanganyar), Mediteran (Desa Baturono, Magelang), dan aluvial (Karangawen, Demak). Masing-masing tanah kemudian dikeringkan di dalam rumah kaca. Sampel tanah diambil untuk dilakukan analisi kimia dan fisik tanah. Sebanyak $12 \mathrm{~kg}$ tanah yang telah siap digunakan kemudian dimasukkan ke dalam setiap pot dengan ukuran tinggi $20 \mathrm{~cm}$ dan diameter $42 \mathrm{~cm}$. Pot kemudian diisi air sampai permukaan tanah tergenang.

Tanah asal Karanganyar dengan perlakuan pemberian pembenah tanah berupa dolomit sebanyak $110 \mathrm{~g} /$ pot dengan campuran bio-slurry dan abu sekam sebanyak 29,64 g/pot. Tanah asal Magelang dengan perlakuan pemberian pembenah tanah berupa kapur sebanyak $110 \mathrm{~g}$, pupuk organik sebanyak $2,2 \mathrm{~kg}$, dan campuran bioslurry dan fosfat sebanyak 50,28 $\mathrm{g} /$ pot. Tanah Demak dengan perlakuan pemberian pembenah tanah berupa pupuk organik sebanyak 2,2 kg dengan campuran bio-slurry, abu sekam, dan fosfat sebanyak $28,38 \mathrm{~g} /$ pot.

Benih padi varietas Inpari 23 yang digunakan dalam penelitian diperoleh dari toko benih. Benih padi direndam menggunakan air selama 24 jam sebelum penanaman benih. Setelah itu tiga benih diambil dan ditanam ke dalam pot sesuai dengan perlakuan. Penanaman benih dilakukan dengan model penanaman tapak macan menggunakan jarak tanam $20 \times 20$ $\mathrm{cm}$.

\section{HASIL DAN PEMBAHASAN}

\subsection{Hasil Analisis Tanah}

Hasil analisis kimia dan fisika awal tanah yang digunakan dapat disajikan pada Tabel 1.

Berdasarkan pada Tabel 1. dapat disimpulkan bahwa ketiga jenis tanah memiliki kandungan $\mathrm{Ca}$ dan $\mathrm{Mg}$ rendah. Jenis tanah asal Karanganyar dan Magelang memiliki pH rendah sebesar 5,54, dan 6,46, sedangkan tanah asal Demak memiliki kandungan C-organik dan $\mathrm{P}$ sangat rendah yaitu sebesar 0,93\% dan 1,04 ppm. Penambahan pembenah tanah berupa dolomit, fosfat, dan pupuk organik bio-slurry perlu dilakukan agar dapat meningkatkan ketersediaan unsur hara, mempercepat dekomposisi bahan organik, memperbaiki struktur tanah, pemantapan agregat tanah, meningktkan kapasitas tukar kation (KTK) dan meningkatkan kapasitas tanah untuk menahan air dan unsur hara (Dariah et al., 2016).

Pemberian dolomit dan pupuk organikpada tanah Karanganyar dan Magelang berfungsi untuk meningkatkan $\mathrm{pH}$ tanah. Menurut Juarsah (2016) pemberian dolomit pada tanah berpasir dapat meningkatkan daya jerap air dan pemberian pada tanah liat dapat memperbaiki struktur tanah dan pori - pori tanah. Pemberian pupuk organik bio-slurry dan fosfat pada tanah Demak dan Magelang berfungsi untuk 
memperbaiki agregat tanah dan meningkatkan unsur hara pada tanah.

Tabel 1. Hasil Analisis Kimia dan Fisika Tanah Asal Karanganyar, Magelang, dan Demak.

\begin{tabular}{|c|c|c|c|c|c|}
\hline No. & Komponen Tanah & Karanganyar & Magelang & Demak & $\begin{array}{c}\text { Kriteria Tanah*) } \\
\text { (Karanganyar, } \\
\text { Magelang, Demak) }\end{array}$ \\
\hline 1. & Pasir (\%) & 51,03 & 75,12 & 0,99 & - \\
\hline 2. & Debu (\%) & 48,78 & 13,75 & 27,80 & - \\
\hline 3. & Liat (\%) & 0,19 & 11,13 & 71,21 & - \\
\hline 4. & Tekstur & GP & GP & $\mathrm{L}$ & GP, GP, L \\
\hline 5. & $\mathrm{pH} \mathrm{H} \mathrm{H}_{2} \mathrm{O}$ & 5,54 & 6,46 & 8,37 & $\mathrm{M}, \mathrm{AM}, \mathrm{AA}$ \\
\hline 6. & $\mathrm{~N}(\%)$ & 1,74 & 0,43 & 0,59 & ST, SR, T \\
\hline 7. & C-Organik (\%) & 3,83 & 0,96 & 0,93 & $\mathrm{~T}, \mathrm{SR}, \mathrm{SR}$ \\
\hline 8. & Bray I $\mathrm{P}_{2} \mathrm{O}_{5}(p p m)$ & 6,31 & 14,57 & 1,04 & ST, ST, SR \\
\hline 9. & $\mathrm{~K}(\mathrm{Cmol} / \mathrm{kg})$ & 1,3200 & 0,4600 & 0,7300 & ST, SR, T \\
\hline 10. & $\mathrm{Ca}(\mathrm{Cmol} / \mathrm{kg})$ & 2.7827 & 1,7864 & 10,3813 & $\mathrm{R}, \mathrm{SR}, \mathrm{S}$ \\
\hline 11. & $\mathrm{Mg}(\mathrm{Cmol} / \mathrm{kg})$ & 0.3718 & 0,3084 & 1,0028 & SR, SR, SR \\
\hline 12. & KTK (Cmol/kg) & 21,19 & 10,56 & 39,54 & $\mathrm{~T}, \mathrm{R}, \mathrm{T}$ \\
\hline 13. & C/N Ratio & 2,20 & 2,23 & 1,57 & $\mathrm{SR}, \mathrm{SR}, \mathrm{SR}$ \\
\hline
\end{tabular}

Keterangan : Hasil Analisis Laboratorium Tanah RC Getas

*) GP : Geluh Pasir, L : Lempung, A : Alkali, AA : Agak Alkali, M : Masam, AM : Agak Masam, ST : Sangat Tinggi, $T$ : Tinggi, $S$ : Sedang, $R$ : Rendah, dan SR : Sangat Rendah.

Menurut Yulina (2019) bahan organik dapat memperbaiki sifat kimia tanah dengan meningkatkan ketersediaan $\mathrm{P}$ tanah dan menurunkan retensi fosfat melalui mekanisme reaksi asam-asam organik sebagai hasil pelapukan bahan organik yang lebih reaktif terhadap logam-logam yang dapat memfiksasi $P$ dalam tanah, sedangkan terhadap sifat fisika tanah dengan membentuk dan memantapkan agregat tanah

Tabel 2. Hasil Akhir Analisis Tanah setelah Penelitian

\begin{tabular}{|c|c|c|c|c|c|}
\hline \multirow{2}{*}{ No } & \multirow{2}{*}{ Pembenah } & \multirow{2}{*}{$\mathrm{BO}(\%)$} & C-Organik (\%) & $N(\%)$ & $\mathrm{pH}$ \\
\hline & & & Akhir & Akhir & Akhir \\
\hline \multicolumn{6}{|c|}{ Tanah Karanganyar (Andosol) } \\
\hline 1 & $\mathrm{R} 1$ & 8,376 & 4,858 & 0,064 & 7,34 \\
\hline 2 & $\mathrm{R} 2$ & 7,656 & 4,440 & 0,161 & 7,26 \\
\hline \multicolumn{6}{|c|}{$\underline{\text { Tanah Magelang (Mediteran) }}$} \\
\hline 1 & $\mathrm{R} 1$ & 6,269 & 3,636 & 0,129 & 7,28 \\
\hline 2 & $\mathrm{R} 2$ & 8,739 & 5,069 & 0,172 & 7,00 \\
\hline \multicolumn{6}{|c|}{ Tanah Demak (Aluvial) } \\
\hline 1 & $\mathrm{R} 1$ & 14,537 & 8,431 & 0,256 & 7,35 \\
\hline 2 & $\mathrm{R} 2$ & 20,877 & 12,109 & 0,372 & 7,10 \\
\hline
\end{tabular}

Berdasarkan Tabel 2. hasil analisis akhir tanah setelah pemberian pembenah tanah menunjukkan bahwa pada tanah asal
Karanganyar dan Magelang nilai $\mathrm{pH}$ meningkat berturut-turut dari yang semula sebesar 5,54 menjadi 7,26 dan 6,46 menjadi 
Agrisaintifika

Jurnal Ilmu-Ilmu Pertanian

Vol. 5, No. 2, 2021

Nugroho, et al. 2021

7,00. Hal tersebut terjadi karena adanya penambahan dolomit sebagai pembenah tanah yang menyebabkan peningkatan $\mathrm{pH}$ pada tanah. Menurut Silahooy (2018) kandungan $\mathrm{Ca}$ pada dolomit dapat meningkatkan $\mathrm{pH}$ pada tanah. Peningkatan $\mathrm{pH}$ juga disebabkan adanya pengikatan antara ion hidroksil dengan kation - kation asam ( $\mathrm{H}$ dan $\mathrm{Al}$ ) sehingga $\mathrm{pH}$ meningkat. Hal ini sesuai dengan pendapat Syahputra et. al. (2015) yang menyatakan bahwa kapur dolomit mengurangi keasaman tanah $(\mathrm{pH})$ oleh perubahan beberapa $\mathrm{H}+$ menjadi air.

Pemberian bahan organik pada tanah asal Magelang dan Demak menyebabkan peningkatan kandungan C-Organik dari yang semula 0,96 menjadi 5,069 dan 0,93 menjadi 12,1. Peningkatan C-Organik dikarena penambahan pupuk organik dengan dosis 40 ton/ha. Hal ini sesuai dengan pendapat Nuro et al. (2016) yang menyatakan bahwa pemberian pupuk organik baik berupa kompos maupun pupuk hayati dapat meningkatkan C-Organik.

\subsection{Tinggi Tanaman}

Hasil analisis ragam menunjukkan bahwa perlakuan pembenah tanah tidak berpengaruh nyata terhadap tinggi tanaman padi. Hasil uji BNT perlakuan jenis dan pembenah tanah terhadap tinggi tanaman padi disajikan pada Tabel 3.

Tabel 3. Rata-rata Tinggi Tanaman Padi Inpari 23 pada Perlakuan Dengan dan Tanpa Pembenah Tanah pada Tanah Asal Tiga Lokasi

\begin{tabular}{lcccc}
\hline \hline \multirow{2}{*}{ Pembenah Tanah } & \multicolumn{3}{c}{ Asal Tanah } & \multirow{2}{*}{ Rata-Rata } \\
\cline { 2 - 3 } & Karanganyar & Magelang & Demak & \\
\hline Tanpa Pembenah & $--------------(\mathrm{cm})----------$ & 74,60 \\
Dengan Pembenah & 72,63 & 75,19 & 75,97 & 73,63 \\
\hline Rata-Rata & 68,08 & 76,15 & 76,67 & \\
\hline
\end{tabular}

Berdasarkan Tabel 3. tinggi tanaman padi varietas Inpari 23 pada perlakuan jenis tanah aluvial asal Demak (L3) dengan penambahan pembenah tanah (R2) memiliki rata - rata tertinggi yaitu $76,32 \mathrm{~cm}$ namun tidak berbeda nyata dengan perlakuan lainnya. Lingkungan merupakan salah satu faktor yang mempengaruhi tinggi tanaman. $\mathrm{Hal}$ ini sesuai dengan pendapat Bustami et al. (2012) yang menyatakan bahwa kondisi lingkungan tempat tumbuh yang sesuai bagi tanaman dapat meningkatkan pertumbuhan dan produksi tanaman. Salah satu faktor lingkungan yang dapat mempengaruhi pertumbuhan tanaman yaitu jenis tanah. Jenis tanah mempengaruhi ketesediaan unsur hara yang dibutuh kan tanaman untuk pertumbuhan. Hal ini sesuai dengan pendapat Nurmasyitah et al. (2013) yang menyatakan bahwa perbedaan jenis tanah mempengaruhi petumbuhan tanaman dikarenakan adanya perbedaan $\mathrm{pH}$, KTK dan unsur hara pada tanah.

\subsection{Jumlah Anakan}

Hasil analisis ragam menunjukkan bahwa perlakuan interaksi antara perlakuan pembenah tanah dengan lokasi asal tanah berpengaruh nyata terhadap jumlah anakan tanaman padi.Hasil uji BNT perlakuan jenis dan pembenah tanah terhadap jumlah anakan tanaman padi disajikan pada Tabel 4. Berdasarkan Tabel 4. jumlah anakan pada jenis tanah andosol asal Karanganyar (L1) dan jenis tanah mediteran asal Magelang (L2), perlakuan pembenah tanah (R2) tidak berbeda nyata dibanding tanpa pembenah tanah (R1). Jumlah anakan pada jenis tanah asal Demak (L3), perlakuan pembenah tanah (R2) berbeda nyata $(P<0,05)$ dibanding tanpa pembenah tanah (R1). 
Tabel 4. Rata-rata Jumlah Anakan Tanaman Padi Inpari 23 pada Perlakuan Dengan dan Tanpa Pembenah Tanah pada Tanah Asal Tiga Lokasi

\begin{tabular}{|c|c|c|c|c|}
\hline \multirow{2}{*}{ Pembenah Tanah } & \multicolumn{3}{|c|}{ Asal Tanah } & \multirow{2}{*}{ Rata-Rata } \\
\hline & Karanganyar & Magelang & Demak & \\
\hline \multicolumn{5}{|c|}{-------------(tangkai)------------ } \\
\hline Tanpa Pembenah & $2,78 \mathrm{~cd}$ & $4,09 a b$ & $3,34 b c$ & 3,40 \\
\hline Dengan Pembenah & $2,03 d$ & $4,01 \mathrm{abc}$ & $5,05 a$ & 3,69 \\
\hline Rata-Rata & 2,41 & 4,05 & 4,19 & \\
\hline
\end{tabular}

Banyaknya jumlah anakan pada tanah asal Magelang dan Demak dikarenakan adanya penambahan bahan organik berupa pupuk organik. Hal ini sesuai dengan pendapat Syawal et al. (2017) yang menyatakan bahwa pemberian bahan organik pada tanah berpengaruh nyata terhadap jumlah anakan pada tanaman padi. Bahan organik yang ditambahakan juga mampu meningkatkan ketersediaan nutrisi tanaman sehingga pertumbuhan tanaman lebih optimal. Hal ini sesuai dengan pendapat Affandi et al. (2015) yang menyatakan penambahan bahan organik mampu meningkatkan $\mathrm{pH}, \mathrm{N}$-tersedia, $\mathrm{P}$-tersedia dan K-tersedia pada tanah yang digunakan tanaman dalam proses pertumbuhan.

Ketersediaan air pada tanah juga dapat mempengaruhi banyaknya jumlah anakan pada tanaman padi. Hal ini sesuai dengan pendapat Mawardi (2016) yang menyatakan bahwa rendahnya kandungan air pada tanah maka semakin berkurang kemampuan tanaman untuk menghasilkan anakan.

\subsection{Bobot Brangkas Tajuk Tanaman}

Hasil analisis ragam menunjukkan bahwa perlakuan interaksi antara pembenah tanah dengan lokasi tanah berpengaruh nyata terhadap bobot segar jerami tanaman padi. Perlakuan pembenah tanah dan lokasi tanah tidak berpengaruh nyata terhadap bobot segar jerami. Perlakuan lokasi tanah berpengaruh nyata terhadap bobot kering jerami.Perlakuan pembenah tanah dan interaksi antara pembenah tanah dengan lokasi tanah berpengaruh nyata terhadap bobot kering brangkas tajuk tanaman. Hasil uji BNT perlakuan lokasi dan pembenah tanah terhadap bobot jerami tanaman padi disajikan pada Tabel 5.

Tabel 5. Rata-rata Bobot Brangkas Tajuk Tanaman Tanaman Padi Inpari 23 pada Perlakuan Dengan dan Tanpa Pembenah Tanah pada Tanah Asal Tiga Lokasi

\begin{tabular}{|c|c|c|c|c|}
\hline Pembenah Tanah & \multicolumn{3}{|c|}{ Asal Tanah } & \multirow[t]{2}{*}{ Rata- Rata } \\
\hline & Karanganyar & Magelang & Demak & \\
\hline \multicolumn{5}{|c|}{ Bobot Segar } \\
\hline Tanpa Pembenah & $91,00 c$ & $162,00 \mathrm{~b}$ & $193,50 \mathrm{~b}$ & \multirow{3}{*}{$\begin{array}{l}148,83 a \\
192,74 a\end{array}$} \\
\hline Dengan Pembenah & $67,23 c$ & $206,00 b$ & $305,00 a$ & \\
\hline Rata-Rata & $79,12 b$ & $\begin{array}{c}184,00 a \\
\text { Bobot Kering }\end{array}$ & $249,25 a$ & \\
\hline Tanpa Pembenah & $46,33 d$ & $84,83 \mathrm{bc}$ & \multirow{2}{*}{$\begin{array}{c}75,67 c \\
143,33 a\end{array}$} & $68,94 b$ \\
\hline Dengan Pembenah & $43,17 d$ & $100,83 b$ & & \multirow{2}{*}{$95,78 a$} \\
\hline Rata-Rata & $44,75 b$ & $92,83 a$ & $109,50 a$ & \\
\hline
\end{tabular}

Keterangan : Superskrip berbeda pada kolom yang sama menunjukkan perbedaan nyata $(P<0,05)$ 
Berdasarkan Tabel 5. bobot segar dan kering brangkas bagian tajuk pada jenis tanah andosol asal Karanganyar (L1) dan jenis tanah mediteran asal Magelang (L2), perlakuan pembenah tanah (R2) tidak berbeda nyata dibanding tanpa pembenah tanah (R1). Bobot segar dan kering brangkas bagian tajuk pada jenis tanah asal Demak (L3), perlakuan pembenah tanah (R2) berbeda nyata $(\mathrm{P}<0,05)$ dibanding tanpa pembenah tanah (R1).

Perbedaan bobot segar dan kering tanaman pada tiga jenis tanah dapat disebabkan oleh bahan organik yang ditambahkan pada perlakuan jenis tanah asal Magelang (L2) dan jenis tanah asal Demak (L). Bahan organik yang ditambahkan dapat mempengaruhi ketersediaan air dan meningkatkan kandungan unsur hara dalam tanah. Hal ini sesuai dengan pendapat Intara et al. (2011) yang menyatakan bahwa bahan organik penting bagi tanah karena memiliki daya memegang air yang tinggi. Air merupakan salah satu bahan yang digunakan tanaman untuk fotosintesis. Hal ini sesuai dengan pendapat Arifiani et al. (2018) yang menyatakan bahwa apabila tanaman kekurangan air maka fotosintesis akan terganggu dan menyebabkan hasil asimilat rendah sehingga biomassa yang dihasilkan juga rendah.

\subsection{Indeks Panen}

Hasil analisis ragam menunjukkan bahwa perlakuan jenis dan pembenah tanah pada tanaman padi tidak pengaruh nyata terhadap indeks panen tanaman padi. Hasil uji BNT perlakuan jenis dan pembenah tanah terhadap indeks panen tanaman padi disajikan pada Tabel 6 .

Tabel 6. Rata-rata Indeks Panen Tanaman Padi Inpari 23 pada Perlakuan Dengan dan Tanpa Pembenah Tanah pada Tanah Asal Tiga Lokasi

\begin{tabular}{lcccc}
\hline \hline \multirow{2}{*}{ Pembenah Tanah } & \multicolumn{3}{c}{ Asal Tanah } & \multirow{2}{*}{ Rata-Rata } \\
\cline { 2 - 3 } & Karanganyar & Magelang & Demak & \\
\hline \multirow{2}{*}{ Tanpa Pembenah } & $0,---{ }^{*}-----()------$ & 0,36 \\
Dengan Pembenah & 0,33 & 0,43 & 0,29 & 0,44 \\
Rata-Rata & 0,34 & 0,32 & 0,78 & 0,54 \\
\hline
\end{tabular}

Keterangan : Superskrip berbeda pada kolom yang sama menunjukkan perbedaan nyata $(\mathrm{P}<0,05)$ 
Berdasarkan Tabel 6. dapat diketahui bahwa indeks panen tertinggi terdapat pada pelakuan jenis tanah aluvial Demak 0,78, menurut parameter pertumbuhan vegetatif terbaik ditunjukankan pada jenis tanah asal Demak (L3) kemudian Magelang (L2) dan yang paling rendah adalah jenis tanah asal Karanganyar (L1). Namun pada parameter indeks panen perlakuan dengan nilai terbesar yaitu jenis tanah asal Demak (L3) kemudian jenis tanah asal Karanganyar (L1) dan yang terendah jenis tanah asal Magelang (L2) walaupun hasil yang didapat tidak berberbeda nyata. Indeks panen merupakan rasio bobot gabah dengan total biomassa. Semakin tinggi indeks panen akan semakin baik karena menandakan tingginya bobot gabah pertanaman yang merupakan indikator tingginya produktifitas suatu varietas. Faktor yang mempengaruhi nilai indeks panen yaitu bobot gabah. Hal ini sesuai dengan pendapat Hambali dan Lubis (2015) yang menyatakan bahwa indeks panen dipengaruhi oleh bobot gabah dengan total biomassa yang diperoleh tanaman. Hal tersebut didukung oleh pendapat Suwarto et al. (2018) yang menyatakan bahwa galur yang mempunyai nilai indeks panen tinggi diharapkan mempunyai hasil gabah yang tinggi, karena indeks panen menunjukkan perbandingan distribusi hasil asimilasi antara biomassa hasil dengan biomassa keseluruhan.

\section{KESIMPULAN}

Berdasarkan hasil penelitian dapat disimpulkan bahwa pembenah tanah pada tanaman padi varietas Inpari 23 menunjukkan pertumbuhan tanaman yang lebih tinggi dibanding pada perlakuan tanpa pembenah tanah. Hasil pertumbuhan padi tertinggi pemberian pembenah pada tanah jenis tanah aluvial asal Demak diikuti oleh jenis tanah mediteran asal Magelang dan jenis tanah andosol asal Karanganyar.

\section{DAFTAR PUSTAKA}

Affandi, F. N., B. Siswanto dan Y. Nuraini. 2015. Pengaruh pemberian berbagai jenis bahan organik terhadap sifat kimia tanah pada pertumbuhan dan produksi tanaman ubi jalar di entisol Ngrangkah Pawon, Kediri. J. Tanah dan Sumberdaya Lahan, 2 (2) : 237 - 244.

Anggraini, F., A. Suryanto dan N. Aini. 2013. Sistem tanam dan umur bibit pada tanaman padi sawah (Oryza sativa L.) varietas Inpari 13. J. Produksi Tanaman, 1 (2) : $52-60$.

Arifiani, F. N., B. Kurniasih dan R. Rogomulyo. 2018. Pengaruh bahan organik terhadap pertumbuhan dan hasil padi (Oryza sativa L.) tercekam salinitas. J. Vegetalika, 7 (3) : $30-40$.

Astriah, E., Daniel dan T. Prawitosari. 2017. Analisis jenis dan tingkat serangan hama dan penyakit pada tanaman padi menggunakan alat spektrometer. J. AgriTechno, 10 (2) : $71-88$.

Badan Pusat Statistika. 2019. Berita Resmi Statistik 2019. BPS, Jakarta.

Bustami, Sufardi dan Bakhtiar. 2012. Serapan hara dan efisiensi pemupukan phosfat serta pertumbuhan padi varietas lokal. J. Manajemen Sumberdaya Lahan, 1 (2) : 159 - 170.

Dariah, A., S. Sutomo, N. L. Nurida, W. Hartatik dan E. Pratiwi. 2015. Pembenah Tanah untuk Meningkatkan Produktifitas Lahan Pertanian. Jurnal Sumberdaya Lahan, 9 (2) : 67 - 84.

Hambali, A. dan I. Lubis. 2015. Evaluasi produktivitas beberapa varietas padi. J. Buletin Agrohorti, 3 (2) : 137 - 145.

Intara, Y. I., A. Sapei, N. Sembiring dan M. H. B. Djoefrie. 2011. Pengaruh pemberian bahan organik pada tanah liat dan lempung berliat terhadap kemampuan mengikat air. J. Ilmu Pertanian Indonesia, 16 (2) :130 - 135.

Juarsah, I. 2016. Pemanfaatan Zeolit dan Dolomit Sebagai Pembenah Untuk Meningkatkan Efisiensi Pemupukan Pada Lahan Sawah. Jurnal Agro, 3 (1) : $10-16$.

Kementan. 2020. Statistik Data Lahan Pertanian Tahun 2015 - 2019. Portal Epublikasi Pertanian, Jakarta. 
Mawardi, C.N. Ichsan, Syamsuddin. 2013. Pertumbuhan dan hasil beberapa varietas tanaman padi (Oryza sativa L.) pada tingkat kondisi kekeringan. J. Ilmiah Mahasiswa Pertanian Unsyiah, 1 (1) : $33-47$.

Nurmasyitah, Syafrudin dan M. Sayuthi. 2013. Pengaruh jenis tanah dan dosis fungi mikoriza arbuskular pada tanaman kedelai terhadap sifat kimia tanah. J. Agrista, 17 (3) : 103 - 110.

Nuro, F., D. Priadi dan E. S. Mulyaningsih. 2016. Efek pupuk organik terhadap sifat kimia tanah dan produksi kangkung darat (Ipomoea reptans poir.). Prosiding Seminar Nasional Hasil - Hasil PPM IPB : 29 - 39.

Prananda, R., Indriyanto dan M. Riniarti. 2014. Respon Pertumbuh Bibit Jabon (Anthocephalus cadamba) Dengan Pemberian Kompos Kotoran Sapi Pada Media Penyapihan. Jurnal Sylva Lestari, 2 (3) : $29-38$.

Silahooy, C. 2018. Efek dolomit dan sp-36 terhadap bintil akar, serapan $\mathrm{n}$ dan hasil kacang tanah (Arachis hypogaea L.) pada tanah kambisol. J. Agrologia, 1 (2) : $91-98$.

Suwarto, S. N. Chasanah, I. Dinuriah, R. Pramesthi dan Soraya. 2018. Perakaran dan indeks panen tanaman padi pada kondisi tergenang dan tidak tergenang. J. Penelitian dan Pengabdian Masyarakat, 8 (1) : 133 141.

Syahputra, D., Alibasyah, M. R dan T. Arabia. 2014. Pengaruh kompos dan dolomit terhadap beberapa sifat kimia ultisol dan hasil kedelai (Glycine max L. Merril) pada lahan berteras. J. Manajemen Sumberdaya Lahan, 4 (1) : $535-542$.

Syawal, F., A. Rauf, Rahmawaty dan B. Hidayat. 2017. Pengaruh pemberian kompos sampah kota pada tanah terdegrdasi terhadap produktivitas tanaman padi sawah di Desa Serdang Kecamatan Beringin Kabupaten Deli Serdang. J. Semdi Unaya, 1 (1) : 41 51.

Winata, N. A. S. H., D. R. Lukiwati dan E. D. Purbajanti. 2014. Peningkatan Produksi Dan Kualitas Jerami Sorgum Manis Dengan Pemberian Pupuk Organik Dan Fosfat Dari Sumber Yang Berbeda. Jurnal Litbang Provinsi Jawa Tengah, $12(1): 7-14$.

Yulina, H., R. Denita dan R. Harryanto. 2019. Pengaruh terak baja dan bokashi sekam padi terhadap air tersedia, biomassa tanaman, serta korelasinya pada tanaman cabai merah setelah vegetatif akhir pada andisol lembang. J. Agro Tatanen, 2 (1) : $1-14$ 